\title{
Bacterial contamination of bath-water from spinal cord lesioned patients with pressure ulcers exercising in the water
}

\author{
F Biering-Sørensen ${ }^{*}, 1$, AK Schröder ${ }^{1}$, M Wilhelmsen ${ }^{1}$, B Lomberg ${ }^{1}$, H Nielsen $^{2}$, N Høiby ${ }^{2}$ \\ ${ }^{1}$ Centre for Spinal Cord Injured, Department TH, The Neuroscience Centre, Copenhagen University Hospital, \\ Copenhagen, Denmark; ${ }^{2}$ Department of Clinical Microbiology, Rigshospitalet, Copenhagen University Hospital, \\ Copenhagen, Denmark
}

\begin{abstract}
Aim: To evaluate the bacterial contamination of the water from the microflora of pressure ulcers in para- and tetraplegic patients, when they were exercising in water at $36^{\circ} \mathrm{C}$ for half an hour.

Material: Twelve spinal cord lesioned (SCL) patients with ulcers participated, and six of the 12 SCL patients with healed ulcers constituted a control group.

Methods: The evaluation was performed both with and without the ulcer covered with a moisture reactive occlusive dressing, DuoDERM ${ }^{\circledR}$. Bacterial samples were taken from the bath-water before and after the exercise programmes and additionally specimens were obtained from the ulcer, the patients skin and urine, and from the skin of the physiotherapist who exercised the patient. A similar procedure was carried out in the controls.

Results: The bacteriologic analyses showed no significant difference in the contamination of the bath-water after exercising with or without DuoDERM ${ }^{\circledR}$ covering the ulcers. In half of the patients DuoDERM ${ }^{\circledR}$ loosened. After all exercise programmes with or without DuoDERM $^{\mathbb{R}}$ dressing the water was contaminated with facultative aerobic intestinal bacteria, ie E. faecalis and Enterobacteriaceae (E. coli, Klebsiella species, Proteus species, Enterobacter species). In nearly one-third of the exercise sessions the bath-water was contaminated with $P$. aeruginosa before starting, and after the exercise programmes one fourth of the ulcers were colonized with these pathogens.

Conclusion: The water specimen showed the bacteria from the intestine to be much more prominent than the bacteria coming from the ulcers. Thus the pressure ulcers were of minor importance for the bath-water and ought not to prohibit patients from the potential benefits of water exercise, but chlorination of the water in the training pool seems appropriate.

Spinal Cord (2000) 38, 100-105
\end{abstract}

Keywords: spinal cord injuries; tetraplegia; paraplegia; pressure ulcer; DuoDERM ${ }^{\circledR}$; bacterial contamination

\section{Introduction}

Para- and tetraplegic patients with ulcers, including pressure ulcers have generally not been allowed to exercise in the training pool of our centre, as we have been concerned with the possibility that the microflora from the ulcers could contaminate the bath-water. The bath-water is chlorinated to prevent contamination and to clean it for organic material from sweat, sputum, urine etc. For disinfection chlorine gas $\left(\mathrm{Cl}_{2}\right)$ or sodium hypochloric solution $(\mathrm{NaOCl})$ is used. The chemical reaction results in chloramines ${ }^{1}$, which may irritate the eyes ${ }^{2}$. In addition, trihalomethans may develop (eg chloroform $\left(\mathrm{CHCl}_{3}\right)$, brominedichloromethan

*Correspondence: $\mathrm{F}$ Biering-Sørensen, Centre for Spinal Cord Injured, Department TH2091, The Neuroscience Centre, Rigshospitalet, Copenhagen University Hospital, Blegdamsvej 9, DK-2100 Copenhagen, Denmark
$\left.\left(\mathrm{CHCl}_{2} \mathrm{Br}\right)\right)$. Some trihalomethans are known to be mutagenic and some may be carcinogenic ${ }^{2}$. For these reasons it is important to minimise the chemical reactions in the chlorinated water, not least because the physiotherapists may be working with the patients in the water for $1-2 \mathrm{~h}$ a day, while the patients most often are only exercising for half an hour one to three times a week. Therefore the aim is to keep the content of organic material in the water as low as possible, eg by restriction of the number of people allowed into the water, making sure that good perineal hygiene has been performed as well as a thorough whole body wash before entering the pool. For the same reason we have not allowed patients with ulcers into the pool. The purpose of this study was to evalute the bacterial contamination of water and ulcer, when allowing paraand tetraplegic patients with pressure ulcers to exercise in the water. 


\section{Material and methods}

Twelve spinal cord lesioned (SCL) patients with pressure ulcers (one had an ulcer after an abscess), participated in the study. Their gender, age, neurological level, functional class according to Frankel et $a l^{3}$, years since lesion, months with the ulcer, together with the location of the ulcer are given in Table 1. A control group consisting of six of the $12 \mathrm{SCL}$ patients with healed ulcers, was established (Table 1). All the patients had neurogenic bladder- and bowel paresis. The size of the ulcers differed both at and below skin level and in depth (Table 1), from a superficial skin entrance of $5 \mathrm{~mm}$ to an undermining of $6 \mathrm{~cm}$.

DuoDERM $^{\circledR}$, a moisture reactive occlusive ulcer dressing with a water impermeable polyurethane outer covering, was used ${ }^{4-6}$. Before application of DuoDERM $^{\mathrm{R}}$ the ulcer was cleaned with isotonic saline and a hydrogen peroxide solution 3\%. The DuoDERM $^{\circledR}$ was applied to the skin approximately half an hour before the participant came into the water.

The exercise programme (see below) was carried out in a conventional bath tub (volume 190 litres), which was disinfected with liquid chloramine containing soap $1 \%$ (TREF, AS, Kaalunds Fabrikker, Kokkedal, Denmark) and rinsed with water between the exercise sessions and filled with fresh water from the tap. With this cleaning procedure all bacteria should be killed. The study was carried out without chlorinated water to be able to isolate the microflora from the ulcers or from other sources.

A pre-set programme of exercises was performed by the same physiotherapist: The patients legs were passively moved ten times with knee/hip flexions, hip flexions with straight knees, hip abduction (restricted because of the the rather narrow bath tub), hip adductions and abdominal muscle training with headlift. These exercises were repeated four times during each training period of half an hour. This exercise programme was tailored to simulate movements the patient would have in the training pool.

The ulcer patients performed the training session in the bath tub twice with at least 1 day interval (median 1 day, mean 3.9 days, range $1-10$ days) once with and once without DuoDERM ${ }^{\mathbb{R}}$ covering the ulcer.

In order to study whether bacteria from the ulcers contaminate the water, samples were taken of the bathwater before and after the exercise programme. In addition samples were taken from the ulcer, the skin at a distance of $4 \mathrm{~cm}$ from the ulcer, from the back of the hand of the patient and from the physiotherapist before the exercising programme and from around the DuoDERM ${ }^{\circledR}$ or from the ulcer after the exercises were performed.

Since the patients are liable to have urinary tract infection we also took urine for culture. Except from the ulcer and DuoDERM ${ }^{\mathbb{R}}$ samples the same samples were taken during the control studies.

\section{Bacteriological techniques}

One hundred $\mathrm{ml}$ bath-water was taken from the bath tub and placed in a sterile container, both before and after the exercise programme had been carried out, placed in the refrigerator and the next day the samples were filtrated by a Milliflex-100 system on a $0.22 \mu \mathrm{m}$ membrane. Hereafter the membrane was placed on $5 \%$ bloodagar plate, where the bacteria were cultured aerobically $\left(37^{\circ} \mathrm{C}\right.$ for $\left.48 \mathrm{~h}\right)$, counted and identified. The lower detection limit of the method used is $10 \mathrm{CFU} / \mathrm{L}$.

The skin samples were obtained by wet swab, which was rubbed over the skin with a 'firm' hand. The transport was by Stuart's transport medium.

These bacterial samples were cultured aerobically at $37^{\circ} \mathrm{C}$ for $48 \mathrm{~h}$ on $10 \%$ bloodagar plates and a modified Conradi-Drigalski medium selective for Gram-negative

Table 1 Details of the participating spinal cord lesioned patients and their ulcers

\begin{tabular}{|c|c|c|c|c|c|c|c|}
\hline $\begin{array}{l}\text { Patient } \\
\text { Number }\end{array}$ & Gender & $\begin{array}{l}\text { Age in } \\
\text { Years }\end{array}$ & $\begin{array}{c}\text { Neurological } \\
\text { level }\end{array}$ & $\begin{array}{c}\text { Frankel } \\
\text { class }\end{array}$ & $\begin{array}{l}\text { Years since } \\
\text { spinal cord } \\
\text { lesion }\end{array}$ & $\begin{array}{c}\text { Months with } \\
\text { pressure } \\
\text { ulcer }\end{array}$ & $\begin{array}{c}\text { Location of } \\
\text { ulcer }\end{array}$ \\
\hline 1 & Male & 21 & Th11 & $\mathrm{D}$ & 0.7 & 1.2 & ischial\# \\
\hline $2+C$ & Male & 41 & $\mathrm{C} 4$ & $\mathrm{D}$ & 26 & $0.5^{\mathrm{a}}$ & lumbar region \\
\hline 3 & Female & 34 & Th8 & A & 1.6 & 6 & sacral† \\
\hline $4+C$ & Male & 26 & $\mathrm{C} 4$ & $\mathrm{D}$ & 0.1 & 1.0 & sacral \\
\hline $5+C$ & Female & 52 & Th4 & A & 22 & 18 & ischial $\dagger$ \\
\hline $6+C$ & Female & 32 & Th12 & A & 1.7 & 12 & ischialt,\#,* \\
\hline 7 & Male & 57 & Th7 & A & 29 & 11 & ischialt, \# \\
\hline 8 & Male & 68 & L1 & $\mathrm{D}$ & 29 & 20 & ischial \\
\hline $9+C$ & Male & 23 & $\mathrm{C} 6$ & $\mathrm{~B}$ & 0.4 & 4 & sacral \\
\hline 10 & Male & 38 & $\mathrm{~L} 2$ & $\mathrm{~B}$ & 17 & 36 & maltt \\
\hline 11 & Male & 34 & $\mathrm{~L} 1$ & $\mathrm{D}$ & 17 & 78 & heel†,\# \\
\hline $12+C$ & Male & 20 & Th5 & A & 0.3 & 3 & sacral†,\# \\
\hline
\end{tabular}

$+\mathrm{C}$ : the patient participated also as control after the ulcer was healed, ${ }^{\mathrm{a}}$ This ulcer was caused by an abscess; ischial: over ischial tuberosity; sacral: over sacral bone; mal: over lateral malleolus; *Osteititis of the tuberosity; \#Exudation present; $†$ More than $1 \mathrm{~cm}$ in depth, may be undermined; $\$$ Had in addition a little ischial ulcer in healing 
Table 2 Bacteria isolated from the bath-water before and after the exercise programme carried out with spinal cord lesioned patients in a bath tub with fresh water. In the ulcer-group $(n=12)$ the patients were studied both with and without DuoDERM ${ }^{\circledR}$ covering their ulcer. The control-group $(n=6)$ consisted of patients from the ulcer-group with healed ulcers $(c f$. Table 1)

\begin{tabular}{|c|c|c|c|c|c|c|}
\hline \multirow{3}{*}{$\begin{array}{l}\text { Bacteria isolated in } \\
\text { bath-water }\end{array}$} & \multicolumn{4}{|c|}{ Ulcer-group } & \multicolumn{2}{|c|}{ Control-group } \\
\hline & \multicolumn{2}{|c|}{ With DuoDERM $M^{\circledR}$} & \multicolumn{2}{|c|}{ Without DuoDERM ${ }^{\mathbb{R}}$} & \multicolumn{2}{|c|}{ s. } \\
\hline & Before & After & Before & After & Before & After \\
\hline Aeromonas species & & & 2 & 1 & & \\
\hline Aeromonas hydrophilia & & & 4 & & & \\
\hline P. aeruginosa & 3 & 4 & 3 & 6 & 3 & 3 \\
\hline Pseudomonas species & 5 & 4 & 1 & 4 & 1 & 1 \\
\hline P. stutzeri & & & & & & \\
\hline P. diminuta & & & 1 & & & 1 \\
\hline Stenotrophomonas maltophilia & & & & 1 & & \\
\hline Acinetobacter calcoaceticus & & 3 & 1 & 3 & & 2 \\
\hline Unidentified (G-ned. rods) & 1 & 1 & & & & \\
\hline S. aureus & & 3 & 1 & 2 & & \\
\hline Non-haemolytic streptococci & & 1 & & & & \\
\hline$\beta$-haemolytic streptococci gr. B & & 1 & & 1 & & \\
\hline Bacillus species & 1 & & & & & \\
\hline Enterococci faecalis & & 2 & & 2 & & \\
\hline E. coli & & 3 & & 1 & & \\
\hline K. pneumonia & 1 & 2 & 2 & 2 & & 1 \\
\hline X. oxytoca & & 2 & & & & 2 \\
\hline P. mirabilis & & 1 & & & & \\
\hline P. vulgaris & & 1 & & 1 & & \\
\hline Enterobacter cloacae & & 1 & & 1 & & \\
\hline Enterobacter aerogenes & & & & & & \\
\hline
\end{tabular}

rods (State Serum Institute, Copenhagen, Denmark) The bacteria were identified by conventional methods. Anaerobic bacteria were not investigated.

For clarity we have excluded the skin bacteria $(S$. epidermidis, other coagulase neg. staphylococci, Corynebacteria) from the results.

The study was performed according to 'The Declaration of Helsinki II'. Informed consent was given by each patient before start of the study.

\section{Results}

\section{Bath-water}

Before the exercise programme $7 / 30$ of the samples of bath-water were without bacteria. In average 1.3 bacterial strain was isolated from the positive bathwater specimens before the exercise programme was performed. Following the exercise programme all of the 30 bath-water specimens contained bacteria, and an average 2.2 bacterial strains were isolated. The bacteria isolated are given in Tables 2 and 3 . The number of bacteria was significant higher in the bath-water after the exercise programme in the ulcergroup with DuoDERM ${ }^{\circledR}$ only (Table 2, $P=0.01, \chi^{2}$ test, $d f=1$ ) but the trend was the same for the group without DuoDERM ${ }^{\circledR}$ and the control group. The total number of bacteria and the number of facultative aerobic intestinal bacteria, ie. E. faecalis and Enterobacteriaceae (E. coli, Klebsiella species, Proteus species, and Enterobacter species) showed, from before to after the exercise, no significant differences between the ulcer-groups with or without DuoDERM $^{\circledR} \quad$ (Fisher's exact tests, Table 2). The bath-water showed, from before to after the exercise, significant more often facultative anaerobic intestinal bacteria in both ulcer-groups (Table 2, with DuoDERM $^{\circledR} \quad P<0.001$, without ${ }^{\circledR} \quad$ DuoDERM $^{\circledR}$ $P<0.01, \chi^{2}$-test, $\left.\mathrm{df}=1\right)$.

Table 4 shows bacteria strains isolated from the bathwater after the exercise programme not isolated from the patient or physiotherapist prior to the exercise programme. In only seven of the 30 trials were such bacteria strains not isolated. Fifteen of the $37(41 \%)$ bacteria strains found were intestinal bacteria.

\section{The ulcer}

The ulcers microflora before and after the exercise programme is given in Table 5. In six of the 12 patients the DuoDERM ${ }^{\mathbb{R}}$ loosened. In one patient it fell off completely.

Before the exercise programme, facultative aerobic intestinal bacteria were isolated in ten patients, and $S$. aureus in six patients in the trials with or without DuoDERM ${ }^{\mathbb{R}}$. After the exercise programme, facultative anaerobic intestinal bacteria were isolated in only eight patients, while $S$. aureus was also found in eight patient trials.

Furthermore, $P$. aeruginosa was isolated in six of the trials after the training session. In two of these cases $P$. aeruginosa was isolated from the bath-water 
Table 3 Total number of bacteria isolated (CFU/L) from the bath-water before and after the exercise programme carried out with spinal cord lesioned patients in a bath tub with fresh water. In the ulcer-group the patients were studied both with and without DuoDERM ${ }^{\mathbb{R}}$ covering their ulcer. $\dagger$ Corresponds to those patients, who were not in the control group

\begin{tabular}{|c|c|c|c|c|c|c|}
\hline \multirow{2}{*}{$\begin{array}{l}\text { Patient } \\
\text { Number }\end{array}$} & \multicolumn{4}{|c|}{ 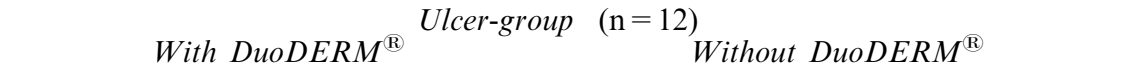 } & \multicolumn{2}{|c|}{ Control group $(\mathrm{n}=6)$} \\
\hline & Before & After & Before & After & Before & After \\
\hline $1 *$ & $\begin{array}{c}10^{4} \text { Pseudomonas } \\
\text { species }\end{array}$ & $10^{6}$ E.coli & $\begin{array}{c}10^{4} \text { Pseudomonas } \\
\text { species }\end{array}$ & $\begin{array}{l}1.2 \cdot 10^{4} \text { incl. } \\
\text { Pseudomonas } \\
\text { species }\end{array}$ & $\dagger$ & $\dagger$ \\
\hline $2 *$ & $\begin{array}{l}5.6 \cdot 10^{2} \text { incl. } \\
\text { Pseudomonas } \\
\text { species }\end{array}$ & $4 \cdot 10^{4}$ K.oxytoca & $\begin{array}{l}4 \cdot 10^{3} \\
\text { Aeromonas species }\end{array}$ & $\begin{array}{c}9 \cdot 10^{4} \\
\text { Pseudomonas } \\
\text { species }\end{array}$ & - & $\begin{array}{c}30 \text { Acinetobacter } \\
\text { calcoaceticus } \\
40 \text { K.oxytoca }\end{array}$ \\
\hline 3 & $\begin{array}{l}3.6 \cdot 10^{5} \text { incl. } \\
\text { K.pneumona }\end{array}$ & $\begin{array}{c}5 \cdot 10^{5} \\
\text { S.aureus } \\
\text { Acinetobacter } \\
\text { calcoaceticus } \\
\text { K.pneumonia }\end{array}$ & $\begin{array}{c}<10^{4} \text { Aeromona } \\
\text { hydrophilia }\end{array}$ & $\begin{array}{c}2 \cdot 10^{4} \\
\text { Acinetobacter } \\
\text { calcoaceticus } \\
70 \text { K.pneumonia }\end{array}$ & $\dagger$ & $\dagger$ \\
\hline 4 & - & $\begin{array}{l}7.4 \cdot 10^{5} \text { incl. } \\
\text { K.pneumonia } \\
\text { P. aeruginosa } \\
\text { E. faecalis }\end{array}$ & $\begin{array}{l}3 \cdot 10^{2} \text { incl. non- } \\
\text { haemolytic } \\
\text { Streptococci } \\
\text { P. Stutzeri }\end{array}$ & $\begin{array}{l}>10^{5} \text { incl. } \\
\text { P. aeruginosa } \\
\text { E.faecalis }\end{array}$ & $\begin{array}{c}8 \cdot 10^{3} \\
\text { P. aeruginosa }\end{array}$ & $\begin{array}{l}9.6 \cdot 10^{5} \mathrm{P} . \\
\text { aeruginosa }\end{array}$ \\
\hline $5^{*}$ & $\begin{array}{c}2 \cdot 10^{6} \text { Bacillus } \\
2 \cdot 10^{4} \text { Pseudomonas } \\
\text { species }\end{array}$ & $\begin{array}{c}4 \cdot 10^{6} \text { P.aeruginosa } \\
10^{4} \text { P.mirabillis }\end{array}$ & $\begin{array}{c}7.5 \cdot 10^{5} \\
\text { P. aeruginosa }\end{array}$ & $\begin{array}{c}1.4 \cdot 10^{6} \\
\text { P. aeruginosa }\end{array}$ & $\begin{array}{c}4 \cdot 10^{3} \\
\text { P.aeruginosa }\end{array}$ & $\begin{array}{c}6 \cdot 10^{3} \text { incl. } \\
\text { Acinetobacter } \\
\text { cacloaceticus } \\
\text { P. aeruginosa }\end{array}$ \\
\hline 6 & $\begin{array}{c}\quad 6.4 \cdot 10^{4} \\
\text { P. aerugnosa } \\
2 \cdot 10^{4} \text { Gram } \\
\text { neg. rods }\end{array}$ & $\begin{array}{c}3 \cdot 10^{4} \\
\text { Pseudomonas } \\
\text { species } \\
8 \cdot 10^{5} \text { P.aeruginosa } \\
2 \cdot 10^{4} \text { E.coli } \\
2.7 \cdot 10^{5} \\
\text { Gram neg. rods }\end{array}$ & $\begin{array}{c}1.2 \cdot 10^{5} \\
\text { S.maltophilia } \\
4 \cdot 10^{3} \text { Pseudomonas } \\
\text { species } \\
10^{4} \text { P.aeruginosa }\end{array}$ & $\begin{array}{c}6.7 \cdot 10^{4} \\
\text { S.maltophilia } \\
70 \text { P.aeruginosa } \\
4.4 \cdot 10^{2} \\
\text { Acinetobacter } \\
\text { calcoaceticus }\end{array}$ & $\begin{array}{c}3.4 \cdot 10^{2} \\
\text { Pseudomonas } \\
\text { species } \\
1.5 \cdot 10^{2} \\
\text { P.aeruginosa }\end{array}$ & $\begin{array}{l}10^{3} \\
\text { Pseudomonas } \\
\text { species } \\
60 \text { P.aeruginosa } \\
4.3 \cdot 10^{2} \text { E-coli }\end{array}$ \\
\hline $7 *$ & $\begin{array}{c}4.4 \cdot 10^{2} \\
\text { P.aeruginosa }\end{array}$ & $\begin{array}{c}10^{2} \text { S.aureus } \\
4 \cdot 10^{3} \\
\text { Acinetobacter } \\
\text { calcoaceticus } \\
3.5 \cdot 10^{3} \text { P.vulgaris } \\
5 \cdot 10^{2} \text { Enterobacter } \\
\text { aerogenes }\end{array}$ & $\begin{array}{c}3 \cdot 10^{2} \\
\text { P.aeruginosa }\end{array}$ & $\begin{array}{c}3 \cdot 10^{4} \text { S.aureus } \\
2.5 \cdot 10^{6} \\
\text { Acinetobacter } \\
\text { calcoaceticus } \\
2 \cdot 10^{5} \text { P.vulgaris }\end{array}$ & $\dagger$ & $\dagger$ \\
\hline $8 *$ & $\begin{array}{l}5.3 \cdot 10^{5} \\
\text { Pseudomonas } \\
\text { species }\end{array}$ & $\begin{array}{l}2 \cdot 10^{4} \beta \text {-haemolytic } \\
\text { Streptococci gr. B } \\
10^{6} \text { Pseudomonas } \\
\text { species }\end{array}$ & $\begin{array}{l}4 \cdot 10^{5} \\
\text { Pseudomonas } \\
\text { species }\end{array}$ & $\begin{array}{c}5 \cdot 10^{4} \beta \text {-haemolytic } \\
\text { Streptococci gr.B } \\
4 \cdot 10^{5} \text { Pseudomonas } \\
\text { species }\end{array}$ & $\dagger$ & $\dagger$ \\
\hline 9 & $\begin{array}{c}2.8 \cdot 10^{2} \\
\text { P.aeruginosa }\end{array}$ & $\begin{array}{c}7.6 \cdot 10^{2} \\
\text { Pseudomonas } \\
\text { species }\end{array}$ & 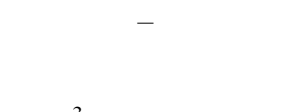 & $\begin{array}{c}>10^{7} \text { P.aeruginosa } \\
5.9 \cdot 10^{5} \\
\text { K.pneumonia }\end{array}$ & - & $10^{2}$ E.coli \\
\hline $10^{*}$ & $\begin{array}{c}10^{3} \begin{array}{c}\text { Pseudomonas } \\
\text { species }\end{array}\end{array}$ & $\begin{array}{c}1.5 \cdot 10^{4} \text { incl. } \\
\text { S.aures } \\
\text { P.aeruginosa } \\
\text { E.coli }\end{array}$ & $\begin{array}{l}10^{3} \text { Aeromonas } \\
\text { species }\end{array}$ & $\begin{array}{l}1.5 \cdot 10^{4} \text { incl. } \\
\text { S.aureus }\end{array}$ & $\dagger$ & $\dagger$ \\
\hline 11 & - & $\begin{array}{c}2.3 \cdot 10^{5} \\
\text { Acinetobacter } \\
\text { calcoaceticus } \\
\text { P. mirabilis } \\
\text { Enterobacter } \\
\text { cloacae }\end{array}$ & $\begin{array}{c}2 \cdot 10^{5} \\
\text { P.aeruginosa }\end{array}$ & $\begin{array}{c}1.5 \cdot 10^{6} \\
\text { Pseudomonas } \\
\text { species } \\
>10^{9} \text { P.aeruginosa } \\
2 \cdot 10^{4} \begin{array}{c}\text { Enterobacta } \\
\text { cloacae }\end{array}\end{array}$ & $\dagger$ & 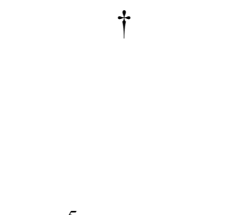 \\
\hline 12 & - & $\begin{array}{c}10^{4} \text { non-haemolytic } \\
\text { Streptococci } \\
10^{6} \text { Pseudomonas } \\
\text { species } \\
5 \cdot 10^{4} \text { K.oxytoca } \\
5 \cdot 10^{5} \text { E.faecalis }\end{array}$ & $\begin{array}{c}1.3 \cdot 10^{6} \text { incl. } \\
\text { Gram neg.rods }\end{array}$ & $\begin{array}{c}>5 \cdot 10^{6} \\
\text { P. auroginosa } \\
3 \cdot 10^{5} \text { E.coli } \\
>5 \cdot 10^{6} \text { E.faecalis }\end{array}$ & - & $8 \cdot 10^{5}$ P.diminuta \\
\hline
\end{tabular}

*DuoDERM ${ }^{\mathbb{R}}$ when covering the ulcer loosened in the trials 
Table 4 Bacteria strains not isolated from the patient of physiotherapist before the exercise programme, but isolated from the bath-water after the exercise programme

\begin{tabular}{|c|c|c|c|}
\hline & \multicolumn{2}{|c|}{ Ulcer-group $(\mathrm{n}=12)$} & \multirow{2}{*}{$\begin{array}{l}\text { Control group } \\
\quad(\mathrm{n}=6)\end{array}$} \\
\hline & With DuoDERM ${ }^{\mathbb{B}}$ & Without DuoDERM ${ }^{\mathbb{B}}$ & \\
\hline P. aerugnosa & 1 & 3 & \\
\hline Pseudomonas species & 3 & 2 & 1 \\
\hline P. diminuta & & & 2 \\
\hline Acinetobacter calcoaceticus & 3 & 3 & \\
\hline S. aureus & 1 & 1 & \\
\hline Non-haemolytic streptococci & 1 & & \\
\hline$\beta$-haemlytic streptococci & 1 & 1 & \\
\hline E-faecalis & & 1 & 2 \\
\hline E. coli & 3 & 1 & \\
\hline K. pneumonia & 1 & 2 & 1 \\
\hline K. oxytoca & 2 & & \\
\hline Enterobacter aerogenes & 1 & & \\
\hline
\end{tabular}

Table 5 Bacteria species isolated from the ulcers or from the edge of the DuoDERM ${ }^{\mathbb{R}}$ before and after an exercise programme was carried through in a bath tub with fresh water both with and without DuoDERM ${ }^{\mathbb{R}}$ covering their ulcer

\begin{tabular}{|c|c|c|c|c|}
\hline \multirow{2}{*}{$\begin{array}{l}\text { Pt. } \\
\text { No. }\end{array}$} & \multicolumn{2}{|c|}{ With DuoDERM ${ }^{\mathbb{R}}$} & \multicolumn{2}{|c|}{ Without DuoDERM $M^{\mathbb{R}}$} \\
\hline & Before & After & Before & After \\
\hline $1 *$ & S. aureus & S. aureus & - & S. aureus \\
\hline $2 *$ & - & - & - & - \\
\hline 3 & $\begin{array}{l}\text { E. faecalis } \\
\text { S. aureus }\end{array}$ & S. aureus & S. aureus & S. aureus \\
\hline 4 & E. faecalis & $\begin{array}{l}\text { K. pneumona } \\
\text { P. aeruginosa }\end{array}$ & S. aureus & $\begin{array}{c}\text { S. aureus } \\
\text { P. aeruginosa }\end{array}$ \\
\hline $5^{*}$ & P. mirabilis & $\begin{array}{l}\text { P. mirabilis } \\
\text { P. aeruginosa } \\
\text { S. aureus }\end{array}$ & $\begin{array}{l}\text { P. mirabilis } \\
\text { E. faecalis }\end{array}$ & $\begin{array}{l}\text { P. mirabilis } \\
\text { P. aeruginosa }\end{array}$ \\
\hline 6 & S. aureus & S. aureus & S. aureus & S. aureus \\
\hline $7 *$ & P. vulgaris & $\begin{array}{l}\text { P. vulgaris } \\
\text { E. faecalis }\end{array}$ & P. vulgaris & $\begin{array}{c}\text { P. vulgaris } \\
\text { Enterobacter } \\
\text { cloacae } \\
\text { Non-haemolytic } \\
\text { streptococci }\end{array}$ \\
\hline $8 *$ & - & - & - & - \\
\hline 9 & - & P. aeruginosa & - & P. stutzeri \\
\hline $10 *$ & - & P. aeruginosa & - & - \\
\hline 11 & $\begin{array}{c}\text { P. mirabilis } \\
\text { Enterobacter } \\
\text { cloacae }\end{array}$ & - & $\begin{array}{l}\text { P. mirabilis } \\
\text { Enterobacter } \\
\text { cloacae }\end{array}$ & $\begin{array}{c}\text { P. mirabilis } \\
\text { Enterobacter } \\
\text { clocae }\end{array}$ \\
\hline 12 & E. faecalis & $\begin{array}{l}\text { E. faecalis } \\
\text { K. oxytoca }\end{array}$ & E. faecalis & $\begin{array}{l}\text { E. faecalis } \\
\text { E. coli }\end{array}$ \\
\hline
\end{tabular}

*DuoDERM ${ }^{\mathbb{R}}$ when covering the ulcer loosened in the trials

before the exercise programme. In no instance was this bacteria found in the ulcer prior to the trials.

Considering the bacteria isolated in the ulcers before the exercise (Table 5) and in the bath-water after the training sessions (Table 3) it was found, that the same intestinal bacteria were isolated in nine instances and $S$. aureus in one.
The skin

Before the exercise programme the skin swab $4 \mathrm{~cm}$ from the ulcer showed, $S$. aureus in two, and Enterococcus faecalis in four specimens, otherwise only skin flora was isolated.

From the skin off the back of the hand of the patients in three of 30 instances were bacteria isolated: $S$. aureus only (two cases), and non-haemolytic Streptococci (one case). In two patients from the ulcer group was $S$. aureus was found on the skin and subsequently, after the exercise, was isolated from the bath-water.

The skin on the back of the hand of the physiotherapist grew $S$. aureus in $1 / 30$ swabs. $S$. aureus was not found in the bath-water after the exercise.

Urine

Significant bacteriuria $\left(\geqslant 10^{5} \mathrm{CFU} / \mathrm{ml}\right)$ was found in $7 / 25$ urine specimens (not cultured in five cases). The bacteria isolated were $P$. aeruginosa (three cases), $P$. mirabilis (three cases), and E. coli (two cases). After the training session the bath-water from the corresponding patients showed $P$. aeruginosa in two and $E$. coli and $P$. mirabilis in one instance each.

$P$. mirabilis in one, and $P$. aeruginosa in two patients were found in the urine before, and in or around the ulcer after the trial.

\section{Discussion}

The number of bacteria isolated in the bath-water after the exercise programme more than doubled compared to before the training session. Nearly one fourth (7/30) of the pre-exercise and all the postexercise bath-water specimens contained bacteria. These figures alone indicate that chlorination of the water in training pools is an appropriate measure to prevent contamination. 
There was no significant difference between the DuoDERM $^{\circledR}$ and non-DuoDERM ${ }^{\circledR}$ ulcer-groups regarding the bacterial contamination of the bathwater. In half of the patients the DuoDERM ${ }^{\circledR}$ dressing loosened indicating that the mechanical forces on the DuoDERM ${ }^{\circledR}$ dressing during half an hour exercising in water reduced the binding capacity of this dressing to the skin. However, it may be of importance for psychological reasons both for the patient and the physiotherapist to cover the ulcer with a dressing. We do not know if the DuoDERM ${ }^{\mathbb{R}}$ dressing will adhere better when used in the training pool with a smaller exercise programme compared with the tub programme. In the control group, as well as in the ulcer group, the bath-water was contaminated with bacteria.

The water specimen showed the facultative aerobic intestinal bacteria to be much more prominent than those coming from the ulcers. However some of these bacteria were also identified in the ulcers prior to the exercise, but as the patients carry the same bacteria in the gut, we cannot identify their origin. We find that the contribution of ulcer bacteria to the bath-water is not of higher importance than contamination from other sources, including faecal contamination, which also previously has been shown to be prominent in swimming pool water ${ }^{8,9}$. All the SCL patients were para- or tetraplegics with neuropathic bladder and bowel. Thus in this study the bacteria specifically from the ulcer to the bath-water was no major problem for the physiotherapist or the patient. In addition, DuoDERM $^{\circledR}$ did not protect the ulcer against contamination.

In $25 \%$ of the 24 ulcer trials, the ulcers were colonized with $P$. aeruginosa after the exercise session. These bacteria were in the bath-water, and came mainly from the tap water, and are common in swimming pools in general ${ }^{8-10}$.

We conclude, that para- and tetraplegic patients with pressure ulcers may exercise in the training pool with chlorinated water, and ought not to be prohibited from the potential benefits of water exercise. A covering of the ulcer is merely for aesthetic reasons.

\section{Acknowledgements}

Convatec has sponsored the study

\section{References}

1 Clemens M, Schöler H-F. Halogenorganische Verbindungen in Scwhimmbadwässern (Halogentated organic compounds in swimming pool waters). Zbl Hyg 1992; 193: 91 - 98. (In German with abstract in English)

2 Miljøstyrelsen (Enviromental Authorities). Kontrol med svømmebade (Monitoring of water quality in swimming pools). In: Vejledning fra Miljostyrelsen, Kobenhavn, 1988; 3: p. 80. (In Danish).

3 Frankel HL et al. The value of postural reduction in the initial management of closed injuries in the spine with paraplegia and tetraplegia. Paraplegia 1969; 7: 179-192.

4 Falanga V. Occlusive Wound Dressings. Why, When, Which? Arch Dermatol 1988; 124: 872-877.

5 Ryan TJ. Granulation Tissue under DuoDerm ${ }^{\circledR}$ : Role of Physical Factors in Fibrinolysis and Angiogenesis. In: Cederholm-Williams SA, Ryan TJ, Lydon MJ (eds.). Fibrinolysis and Angiogenesis in Wound healing. Exerpta Medica. An Elsvier Company 1987; pp. 49-52.

6 Varghese MC, Balin AK, Cartter M, Caldwell D. Local environment of Chronic Wounds Under Synthetic Dressings. Arch Dermatol 1986; 122: $52-56$.

7 Barrow GI, Feltham RKA (eds.). Cowan and Steel's manual for the identification of medical bacteriuria. 3rd edn. Cambridge University Press 1993; pp. 1-331.

8 Tosti E, Voltraa L. Water hygiene of two swimming pools: microbial indicators. J Appl Bacteriology 1988; 65: 87-91.

9 Wiedenmann A, Langhammer W, Botzenhart K. Enterobakterien als Qualitätskriterium bei Roh, Trink- und Badewasser. Vergleichende Untersuchung über das Vorkommen von Enterobakterien, Escherichia coli, coliformen Reimen, Koloniezahl, Fäkalstreptokokken und Pseudomonas aeruginoa. (Enterobacteria as a criterion for the quality of raw-, drinking- and swimming-pool-water. Comparative study of the occurence of Enterobacteria, Escherichia coli, coliforms, colony counts, faecal streptocci and Pseudomnas aeruginosa). Zbl Bakt Hyg B 1988; 187: 91 - 106. (In German with abstract in English).

10 Boltzenhart K, Kampe AA., Streib R. Erkrankungen im Zusammenhang mit Schwimmbadebesuchen-Ergebnis einer Befragung (Diseases aquired by using swimmingpools - Results of an inquiry). Zbl Bakt Hyg B 1988; 186: 118 - 137. (In German with abstract in English). 